\title{
Complications of the anterior retropharyngeal surgical approach to the degenerative cervical spine
}

\author{
S Mihaylova*, D Ferdinandov, K Ninov, A Bussarsky, V Karakostov, K Romansky, M Marinov, V Bussarsky \\ From International Conference for Healthcare and Medical Students 2011 \\ Dublin, Ireland. 4-5 November 2011
}

\section{Introduction}

Anterior cervical retropharyngeal approach for decompression of neural structures is well known and considered as an effective surgical procedure. Opportunities for segment fusion or discoarthroplasty for motion preservation are granted. Both conceptions have their advantages and disadvantages separately from risks of the surgical approach. The aim of this study is to present and analyze the complications of the anterior retropharyngeal surgical approach to the degenerative cervical spine.

\section{Methods}

A database of treated patients at the Clinic of Neurosurgery, Sv. Ivan Rilski Hospital, Sofia, Bulgaria, between January 2006 and August 2011 with cervical spine pathology was used. Certain inclusion and exclusion criteria were applied to select 398 patients with a total of 434 procedures. Comparisons and analysis were done using the observed and recorded initial and follow-up data.

\section{Results}

We present results for intra- and postoperative complications such as dural tears, infections and haemorrhages as well as non-surgically related events. An analysis of risk factors is performed. Risks for adjacent segment degeneration are discussed in details.

\section{Conclusions}

We conclude that the adverse events related to the implant or implantation among groups is not different given the similarity in techniques and treatment course between applied procedures. The most clinically relevant to a patient's quality of life is the adequate decompression

Medical University-Sofia, Bulgaria

(0) 2012 Mihaylova et al; licensee BioMed Central Ltd. This is an Open Access article distributed under the terms of the Creative Commons Attribution License (http://creativecommons.org/licenses/by/2.0), which permits unrestricted use, distribution, and reproduction in any medium, provided the original work is properly cited. of neural structures and expertise based on the patient's individuality.

Published: 9 July 2012

doi:10.1186/1753-6561-6-S4-03

Cite this article as: Mihaylova et al:: Complications of the anterior retropharyngeal surgical approach to the degenerative cervical spine. BMC Proceedings 2012 6(Suppl 4):03.
Submit your next manuscript to BioMed Central and take full advantage of:

- Convenient online submission

- Thorough peer review

- No space constraints or color figure charges

- Immediate publication on acceptance

- Inclusion in PubMed, CAS, Scopus and Google Scholar

- Research which is freely available for redistribution \\ () Biomed Central}

